\title{
Peningkatan Kualitas Air Baku dari Sungai Surabaya dengan Proses Biofiltrasi
}

\section{Improvement of Water Quality Parameters from Surabaya River Using Biofiltration Process}

\author{
NUSA IDAMAN SAID, WAHYU WIDAYAT, RUDI NUGROHO \\ Pusat Teknologi Lingkungan, Badan Pengkajian dan Penerapan Teknologi \\ Gedung Geostech Lantai 3, Kawasan Puspiptek Serpong \\ Email : nusaidamansaid@gmail.com; wdytwahyuw09@gmail.com ; rudi_nugroho@hotmail.com
}

\begin{abstract}
Surabaya River is a source of raw water for the needs of the community in Surabaya and its surrounding areas, including for industrial and the Surabaya water supply company. Along with the rapid growth of settlements and the development of the industrial sector, the Surabaya River pollution level has increased so that the quality of the water does not meet the quality standards required as raw water for drinking water. The most potential parameter that causes the level of pollution is organic pollutants. The concentration of some water quality parameters including organic pollutants in the Surabaya River has exceeded class I water quality standards based on Government Regulation (PP) No. 82 of 2001, namely for allotment of raw water for drinking water. The purpose of this study was to improve the raw water quality such as parameters of suspended solids (TSS), organic substances, detergents and manganese (Mn) through the application of biofilter technology. The study was conducted by operating a biofilter pilot plant consisting of a lamella-type settling tank and a biofilter reactor filled with wasp-type nesting media. The results showed that the biofilter process used can reduce the concentration of TSS, organic matter, detergents and $\mathrm{Mn}$ in raw water. In general, the longer the hydraulic residence time (HRT) in the biofilter pilot plant, the greater the efficiency of removing TSS, organic matter, and detergent in raw water. The experiments results at the conditions of the shortest total HRT of 81 minutes, including HRT of 36 minutes in the settling tank and HRT of 45 minutes in the biofilter reactor, could obtain TSS removal efficiency of $46.92 \%, 15.97 \%$ for organic matter, and $55 \%$ for detergent, where the concentration of these parameters meets the quality standards for drinking water.
\end{abstract}

Keywords: biofiltration, $H R T$, drinking water, water quality

\begin{abstract}
ABSTRAK
Sungai Surabaya merupakan sumber air baku untuk kebutuhan masyarakat di wilayah Surabaya dan sekitarnya, termasuk untuk kebutuhan industri dan air baku PDAM kota Surabaya. Seiring pesatnya pertumbuhan pemukiman dan perkembangan sektor industri, mengakibatkan tingkat pencemaran Sungai Surabaya semakin tinggi sehingga kualitas airnya tidak memenuhi ketentuan baku mutu yang dipersyaratkan sebagai air baku air minum. Parameter yang paling potensial menyebabkan tingkat pencemaran tersebut adalah polutan organik. Konsentrasi beberapa parameter kualitas air termasuk polutan organik di sungai Surabaya telah melebihi baku mutu air kelas I berdasarkan Peraturan Pemerintah (PP) No 82 tahun 2001, yakni untuk peruntukan air baku air minum. Tujuan dari penelitian ini adalah untuk melakukan peningkatan kualitas air baku seperti parameter padatan tersuspensi (TSS), zat organik, deterjen dan mangan (Mn) melalui penerapan teknologi biofilter. Penelitian dilakukan dengan mengoperasikan pilot plant biofilter yang terdiri dari bak pengendap tipe lamella dan reaktor biofilter yang diisi dengan media plastik tipe sarang tawon. Hasil penelitian menujukkan bahwa proses biofilter yang digunakan dapat menurunkan konsentrasi TSS, zat organik, deterjen dan Mn di dalam air baku. Secara umum semakin lama waktu tinggal di dalam pilot plant biofilter, efisiensi penghilangan TSS, zat organik, dan deterjen di dalam air baku semakin besar. Hasil percobaan pada kondisi total waktu tinggal terpendek (total HRT) 81 menit, meliputi HRT di bak pengendap 36 menit dan HRT di reaktor biofilter 45 menit, didapatkan efisensi penghilangan TSS $46,92 \%$, zat organik $15,97 \%$, dan deterjen $55 \%$, dimana konsentrasi parameter-parameter tersebut memenuhi baku mutu untuk air minum.
\end{abstract}

Kata kunci: biofiltrasi, HRT, air minum, kualitas air 


\section{PENDAHULUAN}

\subsection{Latar belakang}

Sungai Surabaya merupakan pecahan dari Sungai Brantas, yang mengalir dari Mojokerto ke Surabaya sepanjang $39,5 \mathrm{~km}$. Sungai tersebut merupakan anak muara Sungai Brantas dimulai dari Mlirip, Mojokerto melewati daerah Wringin Anom, Driyorejo dan Sepanjang sebelum sampai ke Surabaya. Di Wonokromo, Kali Surabaya terpecah menjadi dua anak Kali yaitu Kali Mas dan Kali Wonokromo atau sering disebut Kali Jagir ${ }^{(1)}$. Sungai Surabaya merupakan sumber air baku untuk kebutuhan pemanfaat di wilayah Surabaya dan sekitarnya, termasuk untuk kebutuhan industri dan air baku PDAM kota Surabaya ${ }^{(2)}$.

Seiring pesatnya pertumbuhan pemukiman dan perkembangan sektor industri, mengakibatkan semakin tingginya tingkat pencemaran Sungai Surabaya. Hal tersebut berpengaruh pada menurunnya kualitas air oleh polutan khususnya polutan organik dari limbah domestik maupun limbah industri. Akibatnya Sungai Surabaya memiliki kualitas air baku yang kurang memenuhi ketentuan baku mutu yang dipersyaratkan sebagai air baku air minum ${ }^{(3)}$.

Berdasarkan data sampling kualitas air di intake Ngagel yang dilakukan oleh PDAM dari tahun 2015 sampai dengan tahun $2017^{(4)}$, serta dengan menggunakan perhitungan Indeks Pencemaran (IP), dapat diketahui bahwa tingkat pencemaran air di Intake Ngagel tahun 2015 2017 tergolong dalam pencemaran sedang hingga pencemaran berat. Parameter yang paling potensial menyebabkan tingkat pencemaran tersebut adalah COD, BOD, Zat Organik serta konsentrasi oksigen terlarut (DO).

Konsentrasi COD rata-rata bulanan pada tahun 2015 berkisar antara $10 \mathrm{mg} / \mathrm{l}-15,42 \mathrm{mg} / \mathrm{l}$. konsentrasi rata-rata bulanan tertinggi terjadi pada bulan November dan konsentarsi rata-rata bulanan terendah terjadi pada bulan September. Konsentrasi COD rata-rata bulanan pada tahun 2016 berkisar antara 13,35 mg/l - 18,82 mg/l. Konsentrasi rata-rata bulanan tertinggi terjadi pada bulan Oktober dan konsentarsi rata-rata bulanan terendah terjadi pada bulan Maret. Konsentrasi COD rata-rata bulanan pada tahun 2017 berkisar antara 12,94 mg/l - 19,26 mg/l. Konsentrasi rata-rata bulanan tertinggi terjadi pada bulan Mei dan konsentarsi rata-rata bulanan terendah terjadi pada bulan Oktober. COD rata-rata tahun 2015, 2016 dan 2017 masing-masing sebesar 13,7 mg/l, $14,93 \mathrm{mg} / \mathrm{l}$ dan 16,56 mg/l. Konsentrasi zat organik dalam sungai tersebut telah melebihi baku mutu air kelas I berdasarkan PP No 82 tahun 2001, yakni untuk peruntukan air baku air minum ${ }^{(4)}$.
Disinfeksi adalah proses penting dalam penghilangan mikroorganisme patogen dalam air minum. Dengan memastikan keamanan air minum, desinfeksi adalah tahapan yang penting di dalam proses pengolahan air minum ${ }^{(5,6)}$. Sampai saat ini, proses disinfeksi yang digunakan untuk pengolahan air di Indonesia masih menggunakan senyawa klorin. Sejak tahun 1970-an, telah diakui bahwa desinfeksi dengan khlorin dapat menghasilkan produk sampingan yang berbahaya dan menyebabkan masalah $\operatorname{kesehatan}^{(7)}$. Ada $600-700$ jenis senyawa hasil samping klorinasi (DBP) yang dihasilkan ketika polutan organik yang terjadi secara alami berinteraksi dengan senyawa halogen selama proses pengolahan air(8-10). Reaksi khlorin dengan zat organik di dalam air baku menghasilkan pembentukan trihalometan (THMs), haloacetonitril, asam haloacetat dan senyawa kimia lainnya ${ }^{(11)}$. Senyawa yang paling umum dari hasil samping khlorinasi dalam air minum adalah trihalometan ${ }^{(12)}$, yang meliputi kloroform $\quad\left(\mathrm{CHCl}_{3}\right), \quad$ bromodikhorometan $\left(\mathrm{CHCl}_{2} \mathrm{Br}\right)$, dibromo-khlorometan $\left(\mathrm{CHClBr}_{2}\right)$ dan bromoform $\left(\mathrm{CHBr}_{3}\right)$. Paparan THMs telah terbukti menghasilkan efek buruk terhadap reproduksi dan dapat menyebabkan kanker pencernaan, serta memiliki dampak negatif pada sistem genitourinari $(10,13,14)$.

Trihalometan (THMs) seperti khloroform, dikhlorometan, bromodikhlorometan, dibromokhlorometan, bromoform, 1,2 dikhloroetan, dan karbon tetrakhlorida merupakan senyawa khlor yang dihasilkan akibat proses khlorinasi air. Senyawa tersebut telah terindikasi sebagai senyawa bersifat karsinogen. Hal ini mendorong U.S EPA untuk menentukan batas kandungan maksimum THMs sebesar $100 \mu \mathrm{g} / /^{(15)}$.

Salah satu alternatif untuk menghilangkan senyawa prekursor trihalometan adalah dengan proses peruraian secara biologis atau biodegradasi. Filtrasi biologis atau biofiltrasi adalah proses untuk meningkatkan proses pengolahan air ${ }^{(16,17)}$. Proses ini menggunakan bakteri atau mikro-organisme yang dibutuhkan untuk memecah atau menguraikan polutan yang ada di dalam air ${ }^{(18,19)}$. Media filter yang digunakan sebagai tempat tumbuhnya bakteri harus mempunyai luas permukaan yang besar dan harus memiliki permukaan kasar di mana bakteri atau mikro-organisme dapat dengan mudah tumbuh(20). Media tersebut termasuk karbon aktif(21,22), kerikil, bio-ball, media keramik, atau media terstruktur dari plastik ${ }^{(19)}$. Filtrasi biologis telah diteliti untuk menghilangkan zat organik alami (Natural Organic Matter, $\mathrm{NOM}^{(21,23)}$ dan zat karbon organik terlarut ${ }^{(22,24)}$. 


\subsection{Tujuan Penelitian}

Tujuan dari penelitian ini adalah untuk melakukan uji coba peningkatan kualitas air baku yang di ambil dari Sungai Surabaya seperti parameter padatan tersuspensi (TSS), zat organik, deterjen dan mangan (Mn) melalui penerapan teknologi biofilter, serta mendapatkan gambaran data kinerja teknologi biofilter yang optimal.

\section{BAHAN DAN METODE}

\subsection{Bahan}

Penelitian dilakukan dengan menggunakan serangkaian pilot plant biofilter yang menggunakan beberapa material terdiri dari pompa umpan, valve pengatur debit aliran, rotameter, unit bak pengendap dan unit reaktor biofilter, blower udara. Bak pengedap yang digunakan adalah tipe lamella dengan volume efektif bak pengendap $14,2 \mathrm{~m}^{3}$, dan volume efektif reaktor biofilter $18 \mathrm{~m}^{3}$. Reaktor biofilter diisi dengan media plastik tipe sarang tawon dengan luas spsesifik $\pm 200 \mathrm{~m}^{2} / \mathrm{m}^{3}$, dengan volume $9 \mathrm{~m}^{3}$ (50\% dari volume reaktor). Dimensi bak pengendap dan reaktor biofilter adalah sebagai berikut :

\section{Bak Pengedap :}

Tipe : Lamella Settling

Dimensi

$\begin{array}{ll}\text { Lebar Bak } & : 2,0 \mathrm{~m} \\ \text { Kedalaman Air } & : 2,5 \mathrm{~m} \\ \text { Panjang bak } & : 3,5 \mathrm{~m} \\ \text { Tinggi Ruang bebas } & : 0,3 \mathrm{~m} \\ \text { Volume Efektif } & : 14,2 \mathrm{~m}^{3}\end{array}$

Reaktor Biofilter:

Dimensi

$\begin{array}{lr}\text { Panjang } & : 4,5 \mathrm{~m} \\ \text { Lebar } & : 2,0 \mathrm{~m} \\ \text { Tinggi } & : 2,6 \mathrm{~m} \\ \text { kedalaman Air } & : 2,0 \mathrm{~m} \\ \text { Tinggi Ruang Bebas } & : 60 \mathrm{~cm} \\ \text { Volume Efektif } & : 18 \mathrm{~m}^{3}\end{array}$

\subsection{Metode}

Proses yang terjadi pada reaktor biofilter adalah proses aerobik sehingga pemberian oksigen dilakukan dengan cara menggunakan blower udara yang diinjeksikan ke dalam reaktor secara terus menerus. Air baku dari Sungai Surabaya dilewatkan ke saringan kasar untuk memisahkan sampah dan kotoran kasar, kemudian dipompa melewati rotameter selanjutnya masuk ke bak pengendap. Rotameter berfungsi untuk melihat debit air baku yang mengalir masuk bak pengendap. Bak pengendap menggunakan sistem lamella, berfungsi untuk mengendapkan padatan tersuspensi yang dapat mengganggu kinerja proses biofilter. Air limpasan dari bak pengendap selanjutnya masuk ke reaktor biofilter sambil dihembus udara secara terus menerus. Di dalam reaktor biofilter diisi dengan media dari bahan plastik tipe sarang tawon yang berfungi sebagai tempat tumbuhnya mikroba yang ada di dalam air.

Air limpasan dari reaktor biofilter merupakan air olahan biofilter, dan selanjutnya masuk ke bak penampung antara. Air limpasan dari bak penampung antara dibuang atau diproses lebih lanjut di unit Instalasi Pengolahan Air. Diagram proses pilot plant biofilter yang digunakan dalam penelitian dapat dilihat pada Gambar 1. Unit pilot plant biofilter yang sudah terpasang dapat dilihat pada Gambar 2.

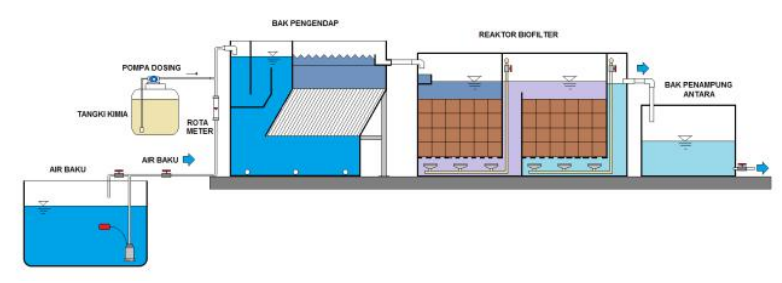

Gambar 1. Diagram Proses Pilot Plant Biofilter untuk Meningkatkan Kualitas Air Baku.

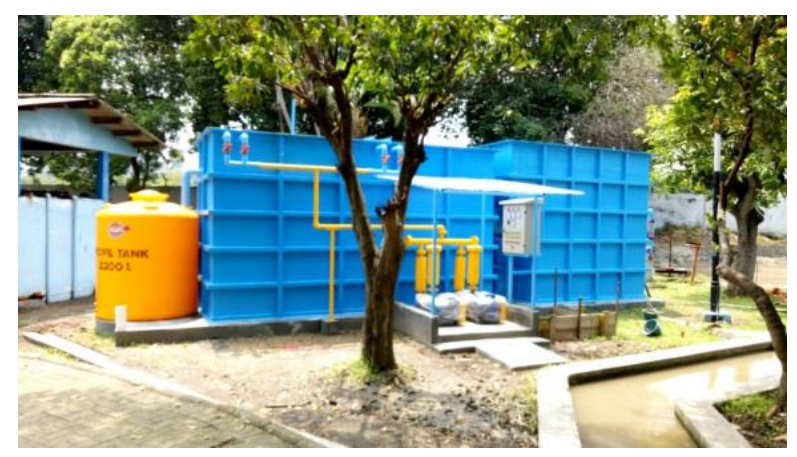

Gambar 2. Unit Pilot Plant Biofilter yang Sudah Terpasang.

Setelah proses berjalan beberapa hari, mikroba akan tumbuh melekat di permukaan media yang ada di dalam reaktor biofilter. Selama melewati media biofilter, polutan organik yang di dalam air baku akan bersentuhan dengan mikroba pengurai polutan yang menempel pada permukaan media biofilter, dan akan terurai senyawa air dan karbon dioksida.

\subsection{Sampling dan Analisa Kualitas Air}

Sampling air dilakukan setiap hari, meliputi air baku yang masuk ke bak pengendap dan air yang keluar reaktor biofilter. Pengambilan sampel sedapat mungkin dilakukan pada jam yang sama setiap hari. Sampel air dimasukkan 
ke dalam botol sampling yang telah disiapkan. Analisa kualitas air dilakukan di laboratorium PDAM Surabaya.

Parameter polutan yang dianalisa antara lain : derajat keasaman $(\mathrm{pH})$, total suspended solid (TSS), oksigen terlarut (DO), zat organik (organic matter, OM), deterjen (MBAS), dan mangan (Mn).

\subsection{Waktu Percobaan}

Uji kinerja pilot plant biofilter dilakukan selama sekitar 5 bulan mulai bulan Februari sampai bulan Juni tahun 2018. Percobaan dilakukan mulai dari proses seeding dan dilanjutkan dengan uji kinerja pilot plant biofilter pada kondisi berbagai variasi waktu tinggal (hydraulic retention time, HRT) di dalam reaktor. Skenario waktu tinggal percobaan pilot plant biofilter untuk meningkatkan kualitas air baku dapat dilihat pada Tabel 1.

Tabel 1. Rencana Skenario Waktu Tinggal Percobaan Pilot Plant Biofilter

\begin{tabular}{|c|c|c|c|c|}
\hline No & Percobaan & $\begin{array}{c}\text { HRT } \\
\text { Bak } \\
\text { Pengendap }\end{array}$ & $\begin{array}{c}\text { HRT } \\
\text { Reaktor } \\
\text { Biofilter }\end{array}$ & $\begin{array}{l}\text { Total HRT Pilot } \\
\text { Plant Biofilter }\end{array}$ \\
\hline 1 & Seeding & $\begin{array}{c}2,37 \text { Jam (142 } \\
\text { Menit) }\end{array}$ & $\begin{array}{c}3 \text { Jam (180 } \\
\text { Menit) }\end{array}$ & $\begin{array}{c}\text { 5,37 Jam } \\
\text { (322 Menit) }\end{array}$ \\
\hline 2 & RUN 1 & $\begin{array}{l}\text { 1,55 Jam } \\
\text { (93 Menit) }\end{array}$ & $\begin{array}{c}2 \mathrm{Jam} \\
\text { (120 Menit) }\end{array}$ & $\begin{array}{c}3,55 \text { Jam } \\
\text { (213 Menit) }\end{array}$ \\
\hline 3 & RUN 2 & $\begin{array}{c}0,78 \\
\text { (49 Menit) }\end{array}$ & $\begin{array}{c}1 \text { Jam } \\
\text { (60 Menit) }\end{array}$ & $\begin{array}{c}1,78 \text { Jam } \\
\text { (109 Menit) }\end{array}$ \\
\hline 4 & RUN 3 & 36 menit & 45 menit & $\begin{array}{c}1,35 \mathrm{JAM} \\
(81 \text { menit })\end{array}$ \\
\hline 5 & RUN 4 & 24 menit & 30 menit & $\begin{array}{c}0,9 \text { JAM } \\
\text { (54 menit) }\end{array}$ \\
\hline
\end{tabular}

Untuk proses seeding, pilot plant biofilter mulai dioperasikan Tanggal 1 Februari 2018 dengan debit air $6 \mathrm{~m}^{3}$ per jam, waktu tinggal di bak pengendap 2,37 Jam (142 menit), dan waktu tinggal di Reaktor Biofilter 3 Jam (180 menit). Proses seeding dilakukan selama hampir satu bulan yakni sampai tanggal 01 Maret 2018 .

Selanjutnya debit air baku diubah menjadi 9 $\mathrm{m}^{3}$ per jam, sehingga waktu tinggal di bak pengendap 1,55 jam (93 menit) dan waktu tinggal di reaktor biofilter menjadi 2 jam (120 menit). Percobaan dilakukan selama tiga minggu yakni mulai tanggal 02 Maret sampai dengan tanggal 20 Maret 2018.

Setelah itu debit air baku diubah lagi menjadi $18 \mathrm{~m}^{3}$ per jam, sehingga waktu tinggal di bak pengendap menjadi 0,78 jam (49 menit) dan waktu tinggal di reaktor biofilter menjadi 1 jam (60 menit). Percobaan dengan debit air baku 18 $\mathrm{m}^{3}$ perjam dilakukan selama sekitar satu bulan yakni mulai tanggal 21 Maret 2018 sampai dengan tanggal 19 April 2018.

Selanjutnya percobaan dilakukan dengan mengubah debit air baku menjadi $24 \mathrm{~m}^{3}$ per jam, sehingga waktu tinggal di bak pengendap 36 menit dan waktu tinggal di reaktor biofilter menjadi 45 menit. Percobaan dengan debit air baku $24 \mathrm{~m}^{3}$ per jam dilakukan selama kurang lebih satu bulan yakni mulai tanggal 20 April 2018 sampai dengan tanggal 17 Mei 2018. Setelah itu debit air limbah diubah menjadi $36 \mathrm{~m}^{3}$ per jam, sehingga waktu tinggal di bak pengendap 24 menit dan waktu tinggal di reaktor biofilter menjadi 30 menit. Percobaan dengan debit air baku $36 \mathrm{~m}^{3}$ per jam dilakukan selama kurang lebih dua minggu yakni mulai tanggal 18 Mei 2018 sampai dengan tanggal 31 Mei 2018. Selama penelitan dilakukan analisa kualitas air inlet dan outlet pilot plant biofilter, dan analisa kualitas air dimulai tanggal 05 Februari 2018.

\section{HASIL DAN PEMBAHASAN}

\subsection{Zat Padat Tersuspensi (Total Suspended Solids, TSS)}

Konsentrasi Total Suspended Solid (TSS) air baku (inlet) dan air olahan (outlet) serta efisiensi penghilangannya ditunjukkan seperti pada Gambar 3.

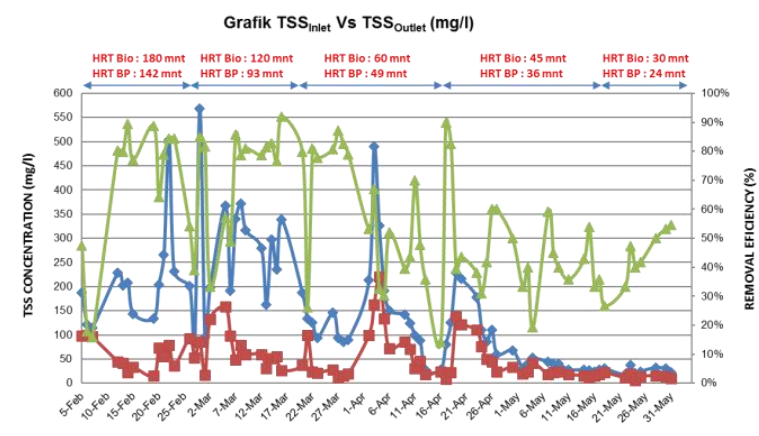

Gambar 3. Grafik Konsentrasi TSS inlet dan outlet Pilot Plant Biofilter Serta Total Efisiensi Penyisihan.

Pada percobaan dengan debit air $6 \mathrm{~m}^{3}$ per jam, waktu tinggal di bak pengendap 2,37 Jam (142 menit) dan waktu tinggal di Reaktor Biofilter 3 Jam (180 menit), konsentrasi TSS di dalam air baku (inlet) berkisar antara $87 \mathrm{mg} / \mathrm{l}$ - $568 \mathrm{mg} / \mathrm{l}$ (rata rata $218,53 \mathrm{mg} / \mathrm{l}$ ). Konsentrasi TSS di dalam air baku cukup tinggi karena pada bulan Februari adalah musim hujan sehingga konsentrasi TSS di intake IPA Ngagel cukup tinggi. Setelah melalui proses pilot plant biofilter konsentrasi TSS turun menjadi $15,5 \mathrm{mg} / \mathrm{l}-100$ $\mathrm{mg} / \mathrm{l}$, atau konsentrasi TSS outlet rata rata 58,91 $\mathrm{mg} / \mathrm{l}$. Efisiensi penghilangan TSS berkisar antara $15,79 \%$ - 89,42 \% (rata rata $66,78 \%$ ).

Pada percobaan dengan debit air $9 \mathrm{~m}^{3}$ per jam, waktu tinggal di bak pengendap 1,55 Jam (93 menit) dan waktu tinggal di Reaktor Biofilter 2 Jam (120 menit), konsentrasi TSS di dalam air 
baku (inlet) berkisar antara $162 \mathrm{mg} / \mathrm{l}-372 \mathrm{mg} / \mathrm{l}$ (rata rata $274 \mathrm{mg} / \mathrm{l})$. Konsentrasi TSS di dalam air baku cukup tinggi karena pada bulan Maret masih dalam musim hujan. Setelah melalui proses pilot plant biofilter konsentrasi TSS turun menjadi $27 \mathrm{mg} / \mathrm{l}-158 \mathrm{mg} / \mathrm{l}$ (rata rata 69,67 mg/l). Efisiensi penghilanggan TSS berkisar antara $33,33 \%-92,01 \%$ (rata rata $73,04 \%$ ).

Pada percobaan dengan debit air $18 \mathrm{~m}^{3}$ per jam, waktu tinggal di bak pengendap 0,78 Jam (49 menit) dan waktu tinggal di Reaktor Biofilter 1 Jam (60 menit), konsentrasi TSS di dalam air baku (inlet) berkisar antara $28 \mathrm{mg} / \mathrm{l}-490 \mathrm{mg} / \mathrm{l}$ (rata rata 146,95 mg/l). Konsentrasi TSS di dalam air baku kadang-kandang masih cukup tinggi tetapi secara rata rata relatif lebih rendah. Setelah melalui proses pilot plant biofilter, konsentrasi TSS turun menjadi $8 \mathrm{mg} / \mathrm{l}-220 \mathrm{mg} / \mathrm{l}$, atau konsentrasi TSS outlet rata rata $64,19 \mathrm{mg} / \mathrm{l}$. Efisiensi penghilanggan TSS berkisar antara $26,12 \%$ - $90 \%$ (rata rata $57,71 \%$ ).

Pada percobaan dengan debit air $24 \mathrm{~m}^{3}$ per jam, waktu tinggal di bak pengendap 36 menit dan waktu tinggal di Reaktor Biofilter 45 menit, konsentrasi TSS di dalam air baku (inlet) berkisar antara $28 \mathrm{mg} / \mathrm{l}-216 \mathrm{mg} / \mathrm{l}$ (rata rata 67,11 mg/l). Percobaan dengan debit $24 \mathrm{~m}^{3} / \mathrm{jam}$ ini dilakukan mulai tanggal 20 April 2018 sampai dengan tanggal 17 Mei 2018. Konsentrasi TSS di dalam air sudah relatif lebih rendah karena sudah mulai masuk musim kemarau. Setelah melalui proses pilot plant biofilter konsentrasi TSS turun menjadi $12 \mathrm{mg} / \mathrm{l}-122 \mathrm{mg} / \mathrm{l}$, atau konsentrasi TSS outlet rata rata $41,92 \mathrm{mg} / \mathrm{l}$. Efisiensi penghilanggan TSS berkisar antara 19,23 \% - $60 \%$ ( rata rata $46,92 \%)$.

Pada percobaan dengan debit air $36 \mathrm{~m}^{3}$ per jam, waktu tinggal di bak pengendap 24 menit dan waktu tinggal di Reaktor Biofilter 30 menit, konsentrasi TSS di dalam air baku (inlet) berkisar antara $10 \mathrm{mg} / \mathrm{l}-38 \mathrm{mg} / \mathrm{l}$ (rata rata 25,56 mg/l). Setelah melalui proses pilot plant biofilter konsentrasi TSS turun menjadi $6 \mathrm{mg} / \mathrm{l}-22 \mathrm{mg} / \mathrm{l}$, atau konsentrasi TSS outlet rata rata $14,67 \mathrm{mg} / \mathrm{l}$. Efisiensi penghilanggan TSS berkisar antara $26,67 \%-54,55 \%$ (rata rata $41,96 \%$ ).

Secara umum semakin kecil waktu tinggal di dalam reaktor pilot plant biofilter efisiensi penghilangan TSS makin turun. Berdasarkan Gambar 3, efisiensi rata rata penghilangan TSS terbesar yaitu $73,04 \%$ terjadi pada saat percobaan dengan debit $9 \mathrm{~m}^{3} / \mathrm{jam}$. Pada saat debit $36 \mathrm{~m}^{3} / \mathrm{jam}$, efisiensi rata rata penghilangan TSS mengalami penurunan menjadi sebesar $41,96 \%$. Dengan semakin besar debit aliran maka kecepatan aliran menjadi lebih besar sehingga efisiensi pengndapan TSS menjadi lebih kecil.

\subsection{Dissolved Oxygen (DO)}

Konsentrasi oksigen terlarut (DO) di dalam air baku (inlet) dan air olahan (outlet) serta prosentase kenaikan konsentrasi DO ditunjukkan seperti pada Gambar 4. Secara keseluruhan konsentrasi DO setelah proses biofilter mengalami kenaikan, hal ini disebabkan karena proses aerasi yang dilakukan di dalam reaktor biofilter.

Pada saat percobaan dengan debit air baku $6 \mathrm{~m}^{3}$ per jam, waktu tinggal di bak pengendap 2,37 Jam (142 menit) dan waktu tinggal di Reaktor Biofilter 3 Jam (180 menit), konsentrasi DO di dalam air baku (inlet) berkisar antara 3,35 $\mathrm{mg} / \mathrm{l}-4,11 \mathrm{mg} / \mathrm{l}$ (DO rata rata $3,75 \mathrm{mg} / \mathrm{l})$. Setelah melalui proses pilot plant biofilter konsentrasi DO naik menjadi 4,17 mg/l - 5,71 mg/l ( DOoutlet rata rata $4,78 \mathrm{mg} / \mathrm{l})$. Prosentase kenaikan DO berkisar antara $15,02 \%-52,53 \%$ (rata rata $28,65 \%)$.

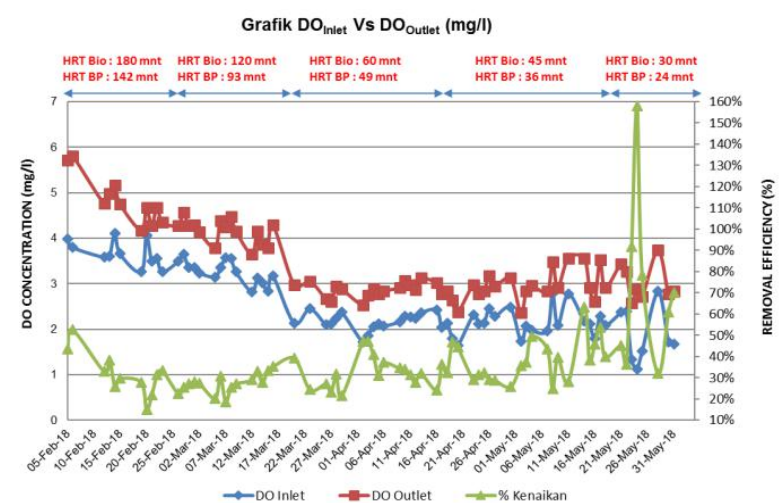

Gambar 4. Grafik Konsentrasi Oksigen Terlarut (DO) inlet dan outlet Biofilter Serta Prosentase Kenaikan.

Pada percobaan dengan debit air baku $9 \mathrm{~m}^{3}$ per jam, waktu tinggal di bak pengendap 1,55 Jam (93 menit) dan waktu tinggal di Reaktor Biofilter 2 Jam (120 menit), konsentrasi DO di dalam air baku (inlet) berkisar antara 2,14 mg/l $3,57 \mathrm{mg} / \mathrm{l}$ (rata rata $3,10 \mathrm{mg} / \mathrm{l}$ ). Setelah melalui proses pilot plant biofilter konsentrasi $D O$ naik menjadi $2,98 \mathrm{mg} / \mathrm{l}-4,38 \mathrm{mg} / \mathrm{l}$ (DO outlet rata rata $3,99 \mathrm{mg} / \mathrm{l})$. Prosentase Kenaikan DO berkisar antara $18,77 \%$ - 39,25 \% (rata rata 31,22\%).

Pada percobaan dengan debit air baku 18 $\mathrm{m}^{3}$ per jam, waktu tinggal di bak pengendap 0,78 Jam (49 menit) dan waktu tinggal di Reaktor Biofilter 1 Jam (60 menit), konsentrasi DO di dalam air baku (inlet) berkisar antara 15,08 mg/l $23,97 \mathrm{mg} / \mathrm{l}$ ( rata rata $19,59 \mathrm{mg} / \mathrm{l}$ ). Setelah melalui proses pilot plant biofilter konsentrasi DO naik menjadi $8,99 \mathrm{mg} / \mathrm{l}-17,03 \mathrm{mg} / \mathrm{l}$ (DO outlet rata rata $8,99 \mathrm{mg} / \mathrm{l})$. Prosentase Kenaikan DO berkisar antara $13,31 \%-52 \%$ rata rata 31,22 $\%)$. 
Pada percobaan dengan debit air baku 24 $\mathrm{m}^{3}$ per jam, waktu tinggal di bak pengendap 36 menit dan waktu tinggal di Reaktor Biofilter 45 menit, konsentrasi DO di dalam air baku (inlet) berkisar antara 1,64 mg/l - 2,46 mg/l (rata rata $2,16 \mathrm{mg} / \mathrm{l})$. Setelah melalui proses pilot plant biofilter, konsentrasi DO naik menjadi 2,37 mg/l $3,52 \mathrm{mg} / \mathrm{l}$ rata rata $2,97 \mathrm{mg} / \mathrm{l})$. Prosentase Kenaikan DO berkisar antara 25,81 \% - 3,52 \% (rata rata $38,30 \%$ ).

Pada percobaan dengan debit air baku 36 $\mathrm{m}^{3}$ per jam, waktu tinggal di bak pengendap 24 menit dan waktu tinggal di Reaktor Biofilter 30 menit, konsentrasi DO di dalam air baku (inlet) berkisar antara $1,12 \mathrm{mg} / \mathrm{l}$ - 2,39 mg/l (rata rata $1,89 \mathrm{mg} / \mathrm{l})$. Setelah melalui proses pilot plant biofilter konsentrasi DO naik menjadi 2,57 mg/l $3,74 \mathrm{mg} / \mathrm{l}$ (rata rata $3,01 \mathrm{mg} / \mathrm{l}$ ). Prosentase Kenaikan DO berkisar antara 32,16 \% - 91,79\% (rata rata 68,09\%). Berdasarkan Gambar 5, persentase keanaikan DO rata-rata berkisar antara 28, $65 \%$ terjadi pada saat percobaan dengan debit $6 \mathrm{~m}^{3} / \mathrm{jam}$. Pada saat debit 36 $\mathrm{m}^{3} / \mathrm{jam}$, prosentase kenaikan konsentrasi DO sebesar $68,09 \%$.

\section{$3.3 \mathrm{pH}$}

$\mathrm{pH}$ air baku (inlet) dan air olahan (outlet) selama percobaan secara lengkap ditunjukkan seperti pada Gambar 5. Pada saat percobaan dengan debit air baku $6 \mathrm{~m}^{3}$ per jam, waktu tinggal di bak pengendap 2,37 Jam (142 menit) dan waktu tinggal di Reaktor Biofilter 3 Jam (180 menit), $\mathrm{pH}$ air baku rata adalah 7,18 , dan setelah melalui proses pilot plant biofilter $\mathrm{pH}$ outlet rata rata adalah 7,83 . Dengan demikian mengalami kenaikan sebesar 9,05\%.

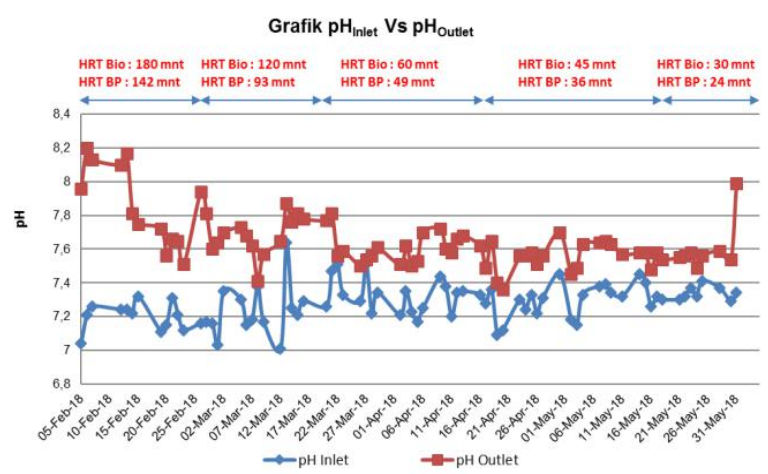

Gambar 5. Grafik pH inlet dan outlet Biofilter.

Pada percobaan dengan debit air baku $9 \mathrm{~m}^{3}$ per jam, waktu tinggal di bak pengendap 1,55 Jam (93 menit) dan waktu tinggal di Reaktor Biofilter 2 Jam (120 menit), pH air baku rata adalah 7,27 , dan setelah melalui proses pilot plant biofilter $\mathrm{pH}$ outlet rata rata adalah 7,70 . Dengan demikian mengalami kenaikan sebesar $5,91 \%$.
Pada percobaan dengan debit air baku 18 $\mathrm{m}^{3}$ per jam, waktu tinggal di bak pengendap 0,78 Jam (49 menit) dan waktu tinggal di Reaktor Biofilter 1 Jam (60 menit), $\mathrm{pH}$ air baku rata adalah 7,33, dan $\mathrm{pH}$ outlet rata rata adalah 7,60. Dengan demikian mengalami kenaikan sebesar $3,68 \%$.

Pada percobaan dengan debit air baku 24 $\mathrm{m}^{3}$ per jam, waktu tinggal di bak pengendap 36 menit dan waktu tinggal di Reaktor Biofilter 45 menit, $\mathrm{pH}$ air baku rata adalah 7,29, dan $\mathrm{pH}$ outlet rata rata adalah 7,55 . Dengan demikian mengalami kenaikan sebesar 3,57 \%.

Pada percobaan dengan debit air baku 36 $\mathrm{m}^{3}$ per jam, waktu tinggal di bak pengendap 24 menit dan waktu tinggal di Reaktor Biofilter 30 menit, $\mathrm{pH}$ air baku rata adalah 7,34. Setelah melalui proses pilot plant biofilter $\mathrm{pH}$ outlet rata rata adalah 7,60. Dengan demikian mengalami kenaikan sebesar 3,54\%.

Dari Gambar 5 tersebut dapat dilihat bahwa pada semua waktu tinggal hidrolis, $\mathrm{pH}$ air olahan selalu lebih tinggi dibandingkan dengan $\mathrm{pH}$ air bakunya. Hal ini disebabkan karena pengaruh aerasi, sehingga karbon dioksida yang terlarut di air menjadi lebih kecil karena digantikan oleh gas oksigen. Gas karbon dioksida di air cenderung membentuk kesetimbangan dan menghasilkan ion bikarbonat. Dengan berkurangnya ion bikarbonat karena berkurangnya karbon dioksida, maka $\mathrm{pH}$ akan naik. Walaupun $\mathrm{pH}$ air olahan naik, namun masih berada pada kisaran netral (pH 7-8), sehingga tidak bermasalah untuk air hasil olahan. Dari keseluruhan kondisi penelitian, $\mathrm{pH}$ air di outlet masih berada pada kisaran netral yakni antara 7-8 dimana baku mutu $\mathrm{pH}$ adalah 69.

\subsection{Zat Organik}

Konsentrasi zat organik (angka permanganat) air baku (inlet) dan air olahan (outlet) serta efisiensi penghilangannya ditunjukkan seperti pada Gambar 6.

Pada saat percobaan dengan debit air baku $6 \mathrm{~m}^{3}$ per jam, waktu tinggal di bak pengendap 2,37 Jam (142 menit) dan waktu tinggal di Reaktor Biofilter 3 Jam (180 menit), zat organik di dalam air baku (inlet) berkisar antara 15,08 mg/l - 23,97 $\mathrm{mg} / \mathrm{l}$ (rata rata 19,59 mg/l). Setelah melalui proses pilot plant biofilter konsentrasi zat organik turun menjadi $8,99 \mathrm{mg} / \mathrm{l}-17,03 \mathrm{mg} / \mathrm{l}$ (rata rata 8,99 $\mathrm{mg} / \mathrm{l})$. Efisiensi penghilangan zat organik berkisar antara $13,31 \%$ - $52 \%$ organic(rata rata $31,22 \%$ ).

Pada percobaan dengan debit air baku $9 \mathrm{~m}^{3}$ per jam, waktu tinggal di bak pengendap 1,55 Jam (93 menit) dan waktu tinggal di Reaktor Biofilter 2 Jam (120 menit), zat organik di dalam air baku (inlet) berkisar antara 16,61 mg/l $22,85 \mathrm{mg} / \mathrm{l}$ (rata rata $18,91 \mathrm{mg} / \mathrm{l})$. Setelah melalui proses pilot plant biofilter konsentrasi zat organik 
turun menjadi $12,64 \mathrm{mg} / \mathrm{l}-17,52 \mathrm{mg} / \mathrm{l}$ (rata rata $14,63 \mathrm{mg} / \mathrm{l}$ ). Efisiensi penghilangan zat organik berkisar antara $9,21 \%-34,37 \%$ (rata rata 22,37 $\%)$.

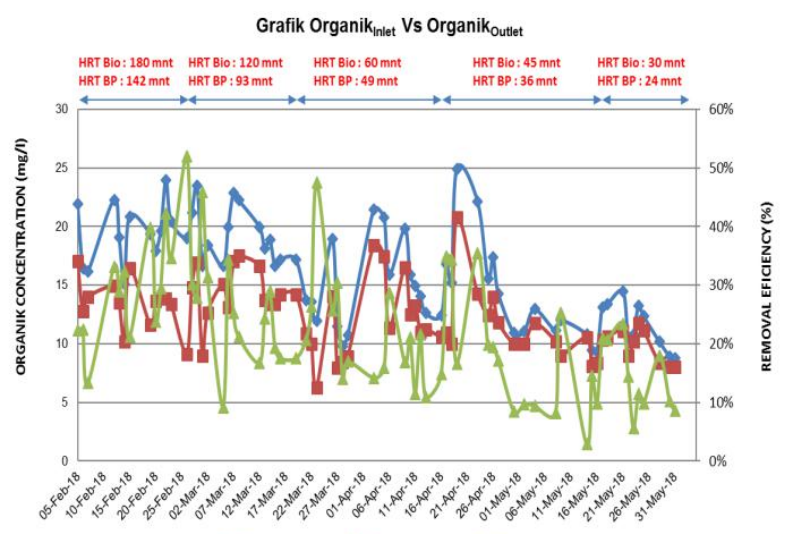

Gambar 6. Grafik Konsentrasi Zat Organik $\left(\mathrm{KMnO}_{4}\right)$ inlet dan outlet Biofilter Serta Total Efisiensi Penghilangan/Penyisihan.

Pada percobaan dengan debit air baku 18 $\mathrm{m}^{3}$ per jam, waktu tinggal di bak pengendap 0,78 Jam (49 menit) dan waktu tinggal di Reaktor Biofilter 1 Jam (60 menit), konsentrasi zat organik di dalam air baku (inlet) berkisar antara $9,8 \mathrm{mg} / \mathrm{l}-24,92 \mathrm{mg} / \mathrm{l}$ (rata rata $16,01 \mathrm{mg} / \mathrm{l}$ ). Setelah melalui proses pilot plant biofilter konsentrasi zat organik turun menjadi $6,28 \mathrm{mg} / \mathrm{l}$ $20,77 \mathrm{mg} / \mathrm{l}$ (rata rata $12,8 \mathrm{mg} / \mathrm{l}$ ). Efisiensi penghilangan zat organik berkisar antara 5,92 \% - $47,49 \%$ (rata rata $20,86 \%$ ).

Pada percobaan dengan debit air baku 24 $\mathrm{m}^{3}$ per jam, waktu tinggal di bak pengendap 36 menit dan waktu tinggal di Reaktor Biofilter 45 menit, konsentrasi zat organik di dalam air baku (inlet) berkisar antara 9,29 mg/l - 21,84 mg/l organic(rata rata $13,65 \mathrm{mg} / \mathrm{l})$. Setelah melalui proses pilot plant biofilter konsentrasi zat organik turun menjadi $7,45 \mathrm{mg} / \mathrm{l}-14,39 \mathrm{mg} / \mathrm{l}$ (rata rata $11,40 \mathrm{mg} / \mathrm{l}$ ). Efisiensi penghilangan zat organik berkisar antara $2,87 \%-37,78 \%$ (rata rata 15,97 $\%)$.

Pada percobaan dengan debit air baku 36 $\mathrm{m}^{3}$ per jam, waktu tinggal di bak pengendap 24 menit dan waktu tinggal di Reaktor Biofilter 30 menit, konsentrasi zat organik di dalam air baku (inlet) berkisar antara $8,79 \mathrm{mg} / \mathrm{l}-14,47 \mathrm{mg} /($ (rata rata $11,41 \mathrm{mg} / \mathrm{l})$. Setelah melalui proses pilot plant biofilter konsentrasi zat organik turun menjadi $8,03 \mathrm{mg} / \mathrm{l}-11,73 \mathrm{mg} / \mathrm{l}$ (rata rata 9,8 $\mathrm{mg} / \mathrm{l})$. Efisiensi penghilangan zat organik berkisar antara 5,64\% - 23,43\% k (rata rata 13,59\%).

Secara umum semakin kecil waktu tinggal di dalam reaktor pilot plant biofilter efisiensi penghilangan zat organik semakin turun. Berdasarkan hasil percobaan, efisiensi rata rata penghilangan zat organik terbesar yaitu 31,22 \% terjadi pada saat percobaan dengan debit 6 $\mathrm{m}^{3} / \mathrm{jam}$. Pada saat debit $36 \mathrm{~m}^{3} / \mathrm{jam}$, efisiensi rata rata penghilangan zat orgnik mengalami penurunan menjadi sebesar $13,59 \%$.

Adanya senyawa organik alami (natural organic matter, NOM) dan bahan organik terlarut (disolved organic matter, DOM)) dalam sumber air adalah merupakan prekursor utama untuk pembentukan senyawa hasil samping disinfeksi (disinfection byproducts, DBPs) dalam air minum. Pembentukan senyawa hasil samping disinfeksi terjadi melalui reaksi antara polutan organik (NOM dan/atau DOM) dengan senyawa khlorin selama proses khlorinasi. Zat organik alami (NOM) adalah campuran kompleks dari senyawa organik yang berasal dari peluruhan vegetasi dan material hewan ${ }^{(7)}$. Sedangkan senyawa organik terlarut (DOM) meliputi banyak senyawa, seperti karbohidrat, senyawa asam humat, asam karboksilat, asam hidrofilik dan asam amino(25). Senyawa-senyawa tersebut telah diidentifikasi sebagai mutagens genotoksik, yang dapat menjadi racun bagi manusia dan kehidupan akuatik(26). Berdasarkan studi epidemiologi, senyawa hasil samping klorinasi berkaitan dengan peningkatan risiko kanker kandung kemih dan usus besar dan kelahiran prematur serta kematian bayi ${ }^{(27,28)}$. Selain itu, paparan jangka panjang terhadap senyawa hasil samping klorinasi dapat berpotensi meningkatkan efek merugikan pada sistem reproduksi(13).

\subsection{Deterjen}

Selama penelitian, besarnya konsentrasi deterjen (MBAS) di air baku berkisar antara $0,01 \mathrm{mg} / \mathrm{l}$ sampai $0,5 \mathrm{mg} / \mathrm{l}$. Untuk air kelas I, yakni air peruntukan untuk air baku air minum, konsentrasi deterjen maksimum adalah $0,2 \mathrm{mg} / \mathrm{l}$. Konsentrasi deterjen di dalam air baku (inlet) dan air olahan (outlet) serta efisiensi penghilangannya ditunjukkan seperti pada Gambar 7.

Pada percobaan dengan debit air baku $6 \mathrm{~m}^{3}$ per jam, waktu tinggal di bak pengendap 2,37 Jam (142 menit) dan waktu tinggal di Reaktor Biofilter 3 Jam (180 menit), konsentrasi deterjen di dalam air baku (inlet) berkisar antara 0,461 $\mathrm{mg} / \mathrm{l}-0,504 \mathrm{mg} / \mathrm{l}$ (rata rata $0,4842 \mathrm{mg} / \mathrm{l})$. Setelah melalui proses pilot plant biofilter konsentrasi deterjen turun menjadi $0,092 \mathrm{mg} / \mathrm{l}-0,469 \mathrm{mg} / \mathrm{l}$ (rata rata $0,3208 \mathrm{mg} / \mathrm{l}$ ). Efisiensi penghilangan deterjen berkisar antara $3 \%-80 \%$ (rata rata 34 $\%)$. 


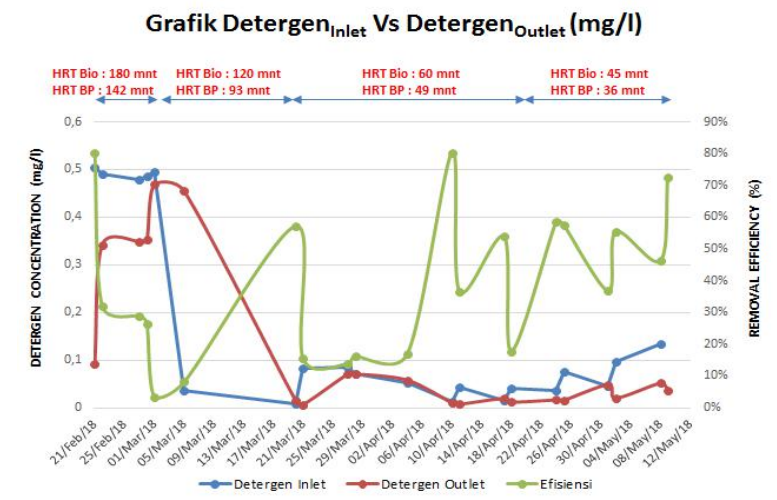

Gambar 7. Konsentrasi Deterjen inlet dan outlet Pilot plant Biofilter serta Efisiensi Penghilangan.

Pada percobaan dengan debit air baku $9 \mathrm{~m}^{3}$ per jam, waktu tinggal di bak pengendap 1,55 Jam (93 menit) dan waktu tinggal di Reaktor Biofilter 2 Jam (120 menit), konsentrasi deterjen di dalam air baku (inlet) berkisar antara 0,0355 $\mathrm{mg} / \mathrm{l}-0,4950 \mathrm{mg} / \mathrm{l}$ (rata rata 0,2653 $\mathrm{mg} / \mathrm{l}$ ). Setelah melalui proses pilot plant biofilter konsentrasi deterjen turun menjadi $0,0152 \mathrm{mg} / \mathrm{l}$ $0,4550 \mathrm{mg} / \mathrm{l}$ (rata rata $0,2351 \mathrm{mg} / \mathrm{l}$ ). Efisiensi penghilangan deterjen berkisar antara $8 \%-57$ $\%$ (rata rata $33 \%$ ).

Pada percobaan dengan debit air baku 18 $\mathrm{m}^{3}$ per jam, waktu tinggal di bak pengendap 0,78 Jam (49 menit) dan waktu tinggal di Reaktor Biofilter 1 Jam (60 menit), konsentrasi deterjen di dalam air baku (inlet) berkisar antara $0,0084 \mathrm{mg} / \mathrm{l}$ - 0,0849 mg/l (rata rata 0,046 mg/l). Setelah melalui proses pilot plant biofilter konsentrasi deterjen turun menjadi $0,0071 \mathrm{mg} / \mathrm{l}-0,0711 \mathrm{mg} / \mathrm{l}$ (rata rata $0,0321 \mathrm{mg} / \mathrm{l})$. Efisiensi penghilangan deterjen berkisar antara $14 \%-80 \%$ (rata rata $31 \%$ ).

Pada percobaan dengan debit air baku 24 $\mathrm{m}^{3}$ per jam, waktu tinggal di bak pengendap 36 menit dan waktu tinggal di Reaktor Biofilter 45 menit, konsentrasi deterjen di dalam air baku (inlet) berkisar antara $0,0372 \mathrm{mg} / \mathrm{l}$ - 0,1338 $\mathrm{mg} / \mathrm{l}($ rata rata $0,0717 \mathrm{mg} / \mathrm{l})$. Setelah melalui proses pilot plant biofilter konsentrasi deterjen turun menjadi 0,0158 mg/l - 0,0517 mg/l (rata rata $0,0316 \mathrm{mg} / \mathrm{l}$ ). Efisiensi penghilangan deterjen berkisar antara $37 \%-73 \%$.

\subsection{Mangan}

Konsentrasi mangan di dalam air baku (inlet) dan air olahan (outlet) serta efisiensi penghilangann ditunjukkan seperti pada Gambar 8. Pada saat percobaan dengan debit air baku 6 $\mathrm{m}^{3}$ per jam, waktu tinggal di bak pengendap 2,37 Jam (142 menit) dan waktu tinggal di Reaktor Biofilter 3 Jam (180 menit), efisiensi penghilangan Mangan berkisar antara 10,13\% $81,97 \%$ (rata rata $48,78 \%$ ).
Pada percobaan dengan debit air baku $9 \mathrm{~m}^{3}$ per jam, waktu tinggal di bak pengendap 1,55 Jam (93 menit) dan waktu tinggal di Reaktor Biofilter 2 Jam (120 menit), efisiensi penghilangan Mangan berkisar antara 6,12 \% $90,91 \%$, (rata rata $48,87 \%$ ).

Pada percobaan dengan debit air baku 18 $\mathrm{m}^{3}$ per jam, waktu tinggal di bak pengendap 0,78 Jam (49 menit) dan waktu tinggal di Reaktor Biofilter 1 Jam (60 menit), efisiensi penghilangan Mangan berkisar antara 5,77 \% - 43,14\% (rata rata $22,79 \%$ ).

Pada percobaan dengan debit air baku 24 $\mathrm{m}^{3}$ per jam, waktu tinggal di bak pengendap 36 menit dan waktu tinggal di Reaktor Biofilter 45 menit, efisiensi penghilangan Mangan berkisar antara $10,29 \%$ - 74,56 \% (rata rata $42,43 \%$ ).

Mangan terlarut ini menjadikan masalah di instalasi pengolahan air minum yakni menimbulkan endapan warna kuning kecoklatan di air hasil olahan setelah post khlorinasi, oleh karena itu sedapat mungkin dihilangkan sampai konsentrasi sekecil mungkin.

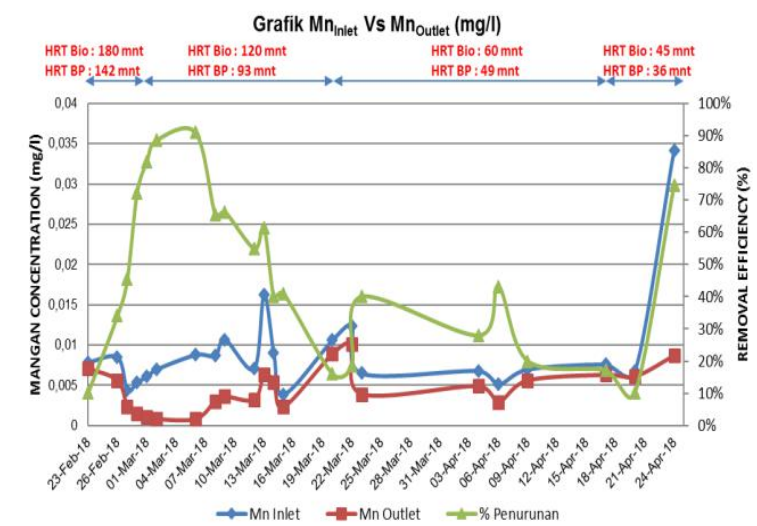

Gambar 8. Konsentrasi Mangan (Mn) inlet dan outlet Biofilter.

\subsection{Rekapitulasi Hasil Penelitian Pilot Plant Biofilter (Februari- Mei 2018)}

Rekapitulasi hasil penelitian pilot plant biofilter untuk meningkatkan kualitas air baku dari Sungai Surabaya dapat dilihat seperti pada Tabel 2. Dari tabel tersebut secara umum efisiensi tertinggi yang dapat dicapai untuk keseluruhan parameter analisa adalah pada kondisi waktu tinggal (HRT) yang paling besar, dan kecenderungannya menurun dengan semakin singkatnya waktu tinggal.

Untuk mengaplikasikan hasil penelitian ini pada skala yang sebenarnya tidak mungkin memilih waktu tinggal yang paling besar yakni total waktu tinggal 322 menit (5,37 jam), karena akan memerlukan instalasi pengolahan air dengan volume yang sangat besar. Oleh karena itu dipilih kondisi waktu tinggal yang paling singkat, dengan kualitas air olahan memenuhi 
target baku mutu air baku untuk air minum (Peruntukan air kelas I).

Tabel 2. Rekapitulasi Hasil Penelitian Pilot plant Biofilter (Pebruari- Mei 2018).

\begin{tabular}{|c|c|c|c|c|}
\hline \multirow{2}{*}{$\begin{array}{c}\mathrm{Q}\left(\mathrm{m}^{3} / \mathrm{jam}\right) \\
\text { HRT } \\
\text { (menit) }\end{array}$} & \multicolumn{4}{|c|}{ Efisiensi Penghilangan Rata-Rata (\%) } \\
\hline & TSS & $\begin{array}{c}\text { Zat } \\
\text { Organik }\end{array}$ & Mangan & Deterjen \\
\hline $\begin{array}{l}\mathrm{Q}=6 \mathrm{~m}^{3} / \mathrm{jam} \\
\mathrm{BP}: 142 \\
\mathrm{BF}: 180\end{array}$ & 66,78 & 31,22 & 48,78 & 34 \\
\hline $\begin{array}{l}\mathrm{Q}=9 \mathrm{~m}^{3} / \mathrm{jam} \\
\mathrm{BP}: 93 \\
\mathrm{BF}: 120\end{array}$ & 73,04 & 22,37 & 48,87 & 33 \\
\hline $\begin{array}{l}\mathrm{Q}=18 \mathrm{~m}^{3} / \mathrm{jam} \\
\mathrm{BP}: 49 \\
\mathrm{BF}: 60\end{array}$ & 57,71 & 20,86 & 22,79 & 31 \\
\hline $\begin{array}{l}\mathrm{Q}=24 \mathrm{~m}^{3} / \mathrm{jam} \\
\mathrm{BP}: 36 \\
\mathrm{BF}: 45\end{array}$ & 46,92 & 15,97 & 22,79 & 55 \\
\hline $\begin{array}{l}\mathrm{Q}=36 \mathrm{~m}^{3} / \mathrm{jam} \\
\mathrm{BP}: 24 \\
\mathrm{BF}: 30\end{array}$ & 41,96 & 13,59 & - & - \\
\hline
\end{tabular}

Berdasarkan pertimbangan tersebut, maka untuk aplikasi di lapangan maka dipilih hasil penelitian pada kondisi total waktu tinggal pilot plant biofilter 81 menit, yakni di bak pengendap 36 menit dan waktu tinggal di reaktor biofilter 45 menit. Kualitas air hasil olahan model test biofilter pada kondisi waktu tinggal 81 menit dapat dilihat seperti pada Tabel 3. Dari hasil tersebut maka sudah mendekati kualitas air kelas I.

Tabel 3. Konsentrasi outlet Model Test Biofilter Pada Kondisi HRT Bak Pengedap 36 Menit dan HRT Biofilter 45 Menit

\begin{tabular}{|c|c|c|c|}
\hline Parameter & $\begin{array}{c}\text { Konsentras } \\
\text { i inlet } \\
\text { Rata-Rata }\end{array}$ & $\begin{array}{c}\text { Konsentras } \\
\text { i outlet } \\
\text { Rata-Rata }\end{array}$ & $\begin{array}{c}\text { Baku } \\
\text { Mutu Air } \\
\text { Kelas I }\end{array}$ \\
\hline $\begin{array}{l}\text { Zat Padat } \\
\text { Tersuspensi } \\
\text { (mg/l) }\end{array}$ & 67,11 & 41,92 & 50 \\
\hline $\begin{array}{l}\text { Kekeruhan } \\
\text { (NTU) }\end{array}$ & 56,89 & 15,84 & - \\
\hline $\begin{array}{l}\text { Zat Organik } \\
(\mathrm{mg} / \mathrm{l})\end{array}$ & 13,65 & 11,40 & 10 \\
\hline $\begin{array}{l}\text { Amoniak - } \\
(\mathrm{mg} / \mathrm{l})\end{array}$ & 0,95 & 0,31 & 0,5 \\
\hline Nitrat ( mg/l) & 1,06 & 0,88 & 10 \\
\hline Nitrit (mg/l) & 0,144 & 0,049 & 0,06 \\
\hline $\mathrm{pH}$ & 7,29 & 7,55 & $6-9$ \\
\hline $\mathrm{DO}(\mathrm{mg} / \mathrm{l})$ & 2,16 & 2,97 & 6 \\
\hline Mangan $(\mathrm{mg} / \mathrm{l}$ & 0,0158 & 0,0071 & 0,1 \\
\hline $\begin{array}{l}\text { Deterjen } \\
(\mathrm{mg} / \mathrm{l})\end{array}$ & 0,0717 & 0,0316 & 0,2 \\
\hline
\end{tabular}

\section{KESIMPULAN}

Dari hasil penelitian pengolahan air baku air minum dengan reaktor biofilter tercelup tanpa aerasi dan dengan aerasi menggunakan media plastik sarang tawon dapat disimpulkan beberapa hal sebagai berikut :

- Proses pilot plant biofilter yang terdiri dari bak pengendap dan reaktor biofilter menggunakan media plastik sarang tawon dapat menurunkan konsentrasi padatan tersuspensi (TSS), zat organik, dan deterjen di dalam air baku.

- Proses aerasi di dalam reaktor biofillter dapat menaikan konsentrasi oksigen terlarut 28,65 $\%$ - 68,09 \%, serta menaikkan $\mathrm{pH} 3,54 \%$ $9,05 \%$.

- Secara umum semakin lama waktu tinggal di dalam pilot plant biofilter, efisiensi penghilangan padatan tersuspensi (TSS), zat organik, deterjen dan mangan $(\mathrm{Mn})$ di dalam air baku semakin besar.

- Berdasarkan pertimbangan teknis dan kualitas air olahan pilot plant biofilter serta biaya konstruksi, untuk basis data perencanaan yang optimum dipilih data hasil percobaan pada kondisi total waktu tinggal (HRT) 81 menit, yakni waktu tinggal (HRT) di bak pengendap 36 menit dan waktu tinggal (HRT) di reaktor biofilter 45 menit.

- Pada kondisi waktu tinggal total di dalam pilot plant biofilter 81 menit, didapatkan efisensi penghilangan TSS 46,92 \%, zat organik 15,97 $\%$, deterjen $55 \%$ dan Mangan 42,43\%.

- Adanya penurunan konsentrasi TSS, zat organik, mangan (Mn) dan deterjen maka dapat mengurangi penggunaan khlor sehingga dapat mengurangi biaya produksi.

- Dengan berkurangnya penggunaan senyawa khlor maka potensi terbentuknya senyawa polutan mikro akibat proses khlorinasi juga akan berkurang.

\section{PERSANTUNAN}

Penulis menyampaikan terima kasih kepada Perusahaan Umum (PERUM) Jasa Tirta I dan PDAM Surya Sembada Surabaya atas bantuan dan fasilitasinya dalam melakukan kajian dalam penelitian ini. Terimakasih juga disampaikan kepada Pusat Teknologi Lingkungan, Badan Pengkajian dan Penerapan Teknologi (BPPT) yang telah mendukung terlaksananya kegiatan ini.

\section{DAFTAR PUSTAKA}

1. Priyono T.S.C., E. Yuliani, R. W. Sayekti. “ (2013). Studi Penentuan Status Mutu Air Di Sungai Surabaya untuk Keperluan Bahan 
Baku Air Minum".Jurnal Teknik Pengairan, Volume 4, Nomor 1 , hlm 53-60.

2. Annonim. (2012). Profil Keanekaragaman Hayati Kota Surabaya. BLH kota Surabaya.

3. Annonim. (2001). PP Nomor 82 Tahun 2001 Tentang Pengendalian pencemaran Alr. Kementerian Lingkungan Hidup. Jakarta.

4. Annonim. (2017). Laporan Pemantauan Kualitas Air Kali Suarabaya Tahun 2015-2017. Perum Jasa Tirta 1 Malang.

5. Crittenden J.C., Trussell R.R., Hand D.W. , Howe K.L., Tchobanoglous G., MWH's (2012). Water Treatment: Principles and Design, third ed., John Wiley and Sons, Hoboken, NJ.

6. Ohar Z., Ostfeld A. (2014). "Optimal design and operation of booster chlorination stations layout in water distribution systems". Water Res. 58.

7. Hua G., Yeats S.A. (2010). "Control of Trihalomethanes in Wastewater Treatment." Florida Water Resources Journal.

8. James B.B. , Todd M.E. , Ratanesh K.S. Michael D.W., Saurabh C. (2015). Trihalomethane exposure and biomonitoring for the liver injury indicator, alanine aminotransferase, in the United States population (NHANES 1999-2006). Sci. Total Environ. 521-522.

9. S.W. Krasner, Philos. Trans. (2009). "The formation and control of emerging disinfection by-products of health concern". A Math. Phys. Eng. Sci. 367 (2009) 4077.

10. Nieuwenhuijsen M.J., Martinez D., Grellier J., Bennett J., Best N., Iszatt N., Vrijheid M., Toledano M.B., (2009). Chlorination disinfection by-products in drinking water and congenital anomalies: review and metaanalyses. Environ. Health Perspect. 117.

11. Platikanov S., Martin J., Tauler R. (2012). Linear and non-linear chemometric modeling of THM formation in Barcelona's water treatment plant. Science of The Total Environment. 432 (2012).

12. Krasner S.W., Weinberg H.S. , Richardson S.D., Pastor S.J. , Chinn R. , Sclimenti M.J., Onstad G.D., Thruston A.D. (2006). Occurrence of a new generation of disinfection byproduct. Environ. Sci. Technol. 40.

13. Richardson S.D., Plewa M.J., Wagner E.D., Schoeny R., Demarini D.M. (2007). "Occurrence, genotoxicity, and carcinogenicity of regulated and emerging disinfection byproducts in drinking water: a review and roadmap for research". Mutat. Res. 636.
14. Grellier J., Bennett J., Patelarou E., Smith R.B., Toledano M.B., Rushton L., Briggs D.J., Nieuwenhuijsen M.J. (2010). Exposure to disinfection by-products, fetal growth, and prematurity: a systematic review and metaanalysis. Epidemiology 21 (3).

15. Craun,G.F. (1988). Surface water supplies and health. Journal American Water Works Association. 80:40-52.

16. Khan M.M.T. , Lewandowski Z. , Takizawa S. , Yamada K. , Katayama H. , Yamamoto K., Ohgaki S. (2009). Continuous and efficient removal of THMs from river water using MF membrane combined with high dose of PAC. Desalination 249.

17.Linlin W. , Xuan Z., Meng Z. (2011). Removal of dissolved organic matter in municipal effluent with ozonation, slow sand filtration and nanofiltration as high quality pre-treatment option for artificial groundwater recharge. Chemosphere 83.

18. Said, N.I. (2006). Aplikasi Proses Biofiltrasi Dan Ultrafiltrasi Untuk Pengolahan Air Minum. JURNAL AIR INDONESIA, Volume 2, Nomor 1.

19. Graham Q., Karen P. (2016). Biological Filtration, www.pondlife.me.uk/ponds/ filtration/biofilter.

20.Said, N.I. (2010). Teknologi Biofiltrasi Dan Ultrafiltrasi Untuk Pengolahan Air Minum. Penerbit : Pusat Teknologi Lingkungan, BPPT. 2010.

21. Han Q., Yan H., Zhang Z., Xue N., Wang Y., Chu Y., Gao B. (2015). Trihalomethanes (THMs) precursorfractions removal by coagulation and adsorption for biotreated municipal wastewater : Molecular weight, hydrophobicity/ hydrophily and fluorescence. Journal of Hazardous Materials. 297.

22. Pramanik B.K., Choo K.H., Pramanik S.K., Suja F., Jegatheesan V. (2015). Comparisons between biological filtration and coagulation processes for the removal of dissolved organic nitrogen and disinfection by-products precursors. International Biodeterioration and Biodegra-dation. 104.

23. Simon F.X., Rudé E., Llorens J., Baig S. (2013). Study on the removal of biodegradable NOM from seawater using biofiltration Desalination. 316.

24. Regnery, J. Barringer, A.D. Wing, C. HoppeJones, J. Teerlink, J.E. Drewes, (2015). Startup performance of a full-scale riverbank filtration site regarding removal of DOC, 
nutrients, and trace organic chemicals. Chemosphere 127.

25. Thurman E.M., Organic Geochemistry of Natural Waters, Martinus Nijhoff/Dr. W. (1985). Junk Publishers, Dordrecht, Netherlands.

26.Zhang F., Wang Y., Chu Y., Gao B., Yue Q., Yang Z., Li Q. (2013). "Reduction of organic matter and trihalomethane formation potential in reclaimed water from treated municipal wastewater by coagulation and adsorption". J. Chem. Eng. 233

27. Bove G.E., Rogerson P.A., Vena J.E. (2007). "Case control study of the geographic variability of exposure to disinfectant byproducts and risk for rectal cancer". Int. J. Health Geogr. 6.

28. Villanueva C.M., Cantor K.P., Grimalt J.O., Malats N., Silverman D., Tardon A., GarciaClosas R., Serra C., Carrato A., CastanoVinyals G., Marcos R., Rothman N., Real F.X., Dosemeci M. , Kogevinas M. (2007). "Bladder cancer and exposure to water disinfection byproducts through ingestion, bathing, showering, and swimming in pools". Am. J. Epidemiol. 165. 